Original papers

\title{
Development of an android APP to calculate thermal comfort indexes on animals and people
}

\author{
Arilson José de Oliveira Júnior ${ }^{\mathrm{a}, *}$, Silvia Regina Lucas de Souza ${ }^{\mathrm{a}}$, Vasco Fitas da Cruz ${ }^{\mathrm{b}}$, \\ Tiago Aparecido Vicentin ${ }^{a}$, Andreia Soares Gonçalves Glavina ${ }^{a}$ \\ ${ }^{a}$ College of Agronomic Science, Universidade Estadual Paulista - UNESP, Av. Universit ária, 3780, 18610-034 Botucatu, SP, Brazil \\ ${ }^{\mathrm{b}}$ Department of Rural Engineering, Universidade de Évora, Largo dos Colegiais 2, 7000 Évora, Portugal
}

A R T I C L E I N F O

\section{Keywords:}

Thermal comfort

Smartphones

App

Android

Arduino

\begin{abstract}
A B S T R A C T
Nowadays, most of the analysis on thermal comfort in the agricultural environment, with particular reference to animal production environments, use indexes that allow the evaluation of the thermal stress level of a given location by means of climatological variables. For the resolution of these indexes there is currently no specific computational system that provides, in loco, the thermal condition of an environment. Thus, the present study aimed to develop a computational system capable of evaluating the thermal comfort of animal production facilities and human work environments. The system was based on the development of an application for smartphones and Android tablets, and the creation of a low cost portable device to measure climatological variables such as air temperature, black globe temperature and relative humidity. The portable device was developed based on the Arduino ATmega1280 microcontroller, along with temperature and relative humidity sensors. The android app was used together with the portable device in two environments, an office and a pig facility. The system showed to be functional in obtaining an in loco diagnosis of thermal comfort of the environments, in which measurements of air temperature, relative humidity and black globe temperature were collected and sent to the application that calculated THI and BGHI. The development of the Android application and portable device can be considered as a low-cost alternative solution for evaluations and monitoring of thermal comfort of animals and people.
\end{abstract}

\section{Introduction}

In order to obtain the optimum productivity of the animals allowing the expression of their genetic potential it is necessary to provide favorable conditions. Likewise, in human work environments the limits of tolerance to heat exposure are ways of preserving workers' health and ensuring the maximum yield and quality of activities. Over the years studies on thermal comfort have become relevant in assessing environmental conditions. Indexes were developed to better measure the comfort of individuals, such as the Temperature and Humidity Index THI (Buffington et al., 1983), Discomfort Index - DI (Thom, 1959) and Black Globe Temperature and Humidity Index - BGHI (Buffington et al., 1981), based on climatic measures such as air temperature, black globe temperature, relative humidity and air velocity. Thermal comfort can be defined as the condition of full comfort that an individual expresses in relation to the environment in a thermal perspective (ASHRAE Standard and 55P, (2010); Nematchoua et al., 2013; Din et al., 2014).

Currently the application of these indexes and analysis of their results are done through the installation of sensors that perform measurements of climatological variables together with electronic data storage devices (data loggers) able to record the data (Alves et al., 2007; Jácome et al., 2007; Fiorelli et al., 2010; Gomes et al., 2011; Fernandes et al., 2011; Sarubbi et al., 2012; Carvalho et al., 2014; Oliveira Júnior et al., 2015) and by means of specialized software developed for the Windows operating system (Mollo Neto and Nääs, 2014, Mollo Neto et al., 2014, Angelo et al., 2014). This type of measurement and data analysis is effective when it is necessary to monitor and analyze large volumes of data collected over long periods. However for an in loco analysis with low data volume and smaller collection periods of approximately $30-60 \mathrm{~min}$, the need for a previous programming of the electronic data storage devices, the deployment of a set of sensors according to the index to use and the configuration of the proprietary software to receive the data, makes this process sometimes expensive and unachievable.

Thus, the aim of this study was to develop an application for smartphones and Android tablets and a low cost portable device in

\footnotetext{
* Corresponding author.

E-mail addresses: arilson.oliveira@unesp.br (A.J. de Oliveira Júnior), silvia.souza@fca.unesp.br (S.R.L.de Souza), vfc@uevora.pt (V.F. da Cruz).
} 
Table 1

Thermal comfort limits for broilers, cattle and pigs according to the indexes BGHI and THI.

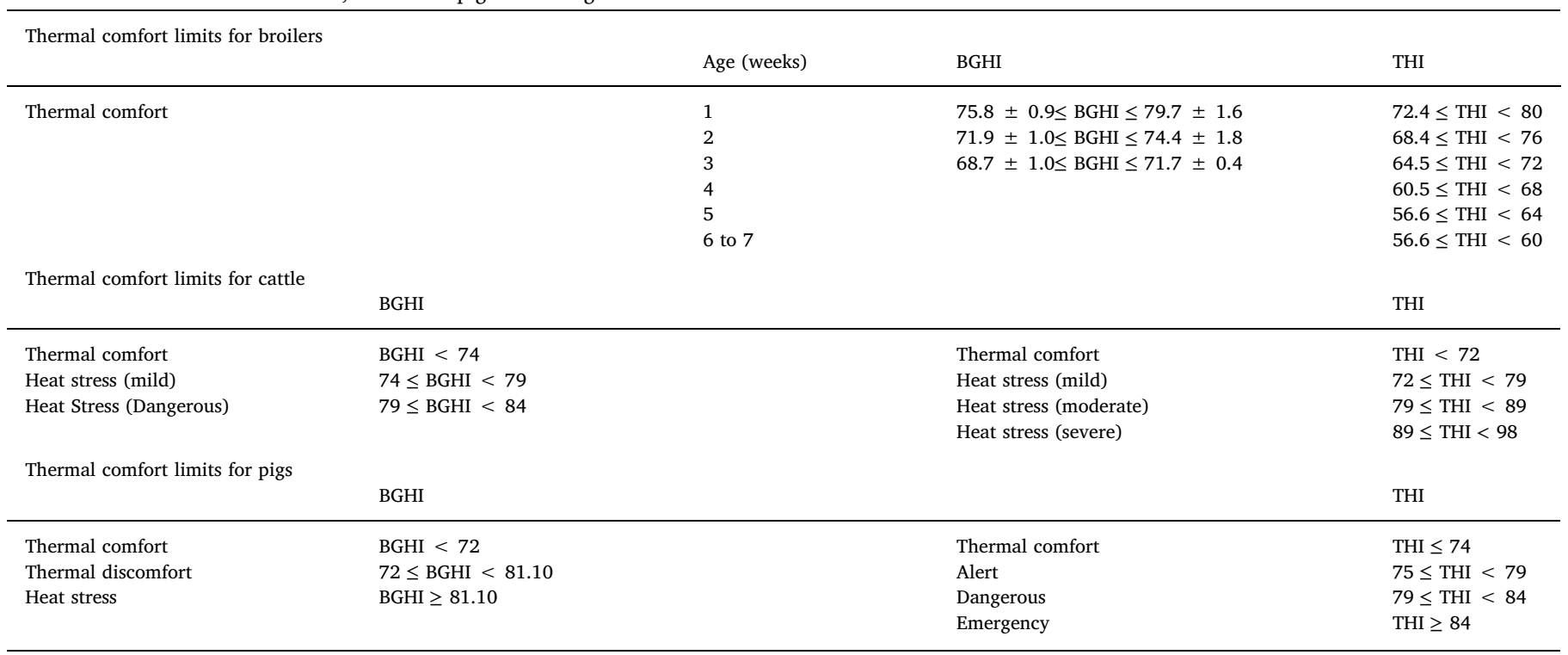

A.

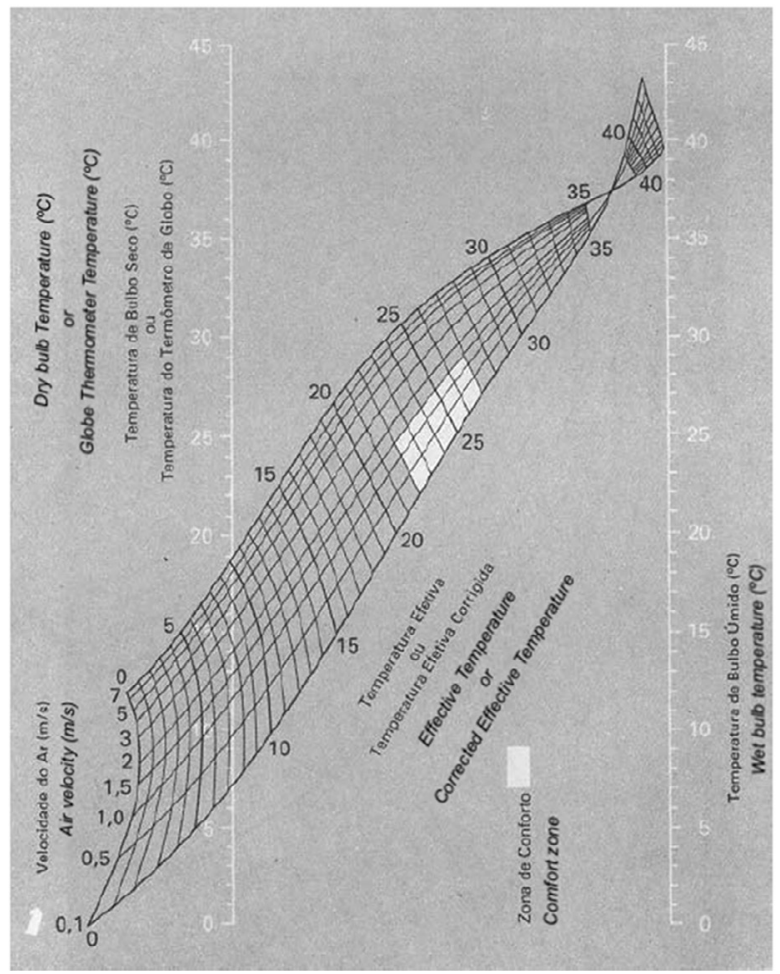

Fig. 1. Two-dimensional Diagram (A.), variable correlation (B.)

Adapted from Frota and Schiffer, 2006

order to calculate the in loco thermal comfort indexes of animal production facilities and human work environments.

\section{Materials and methods}

The study was carried out in two parts: I - development of an Android mobile app; II - creation of a portable low-cost device for measuring and sending climatological data to the app developed via Bluetooth communication. The development and tests were carried out
B.

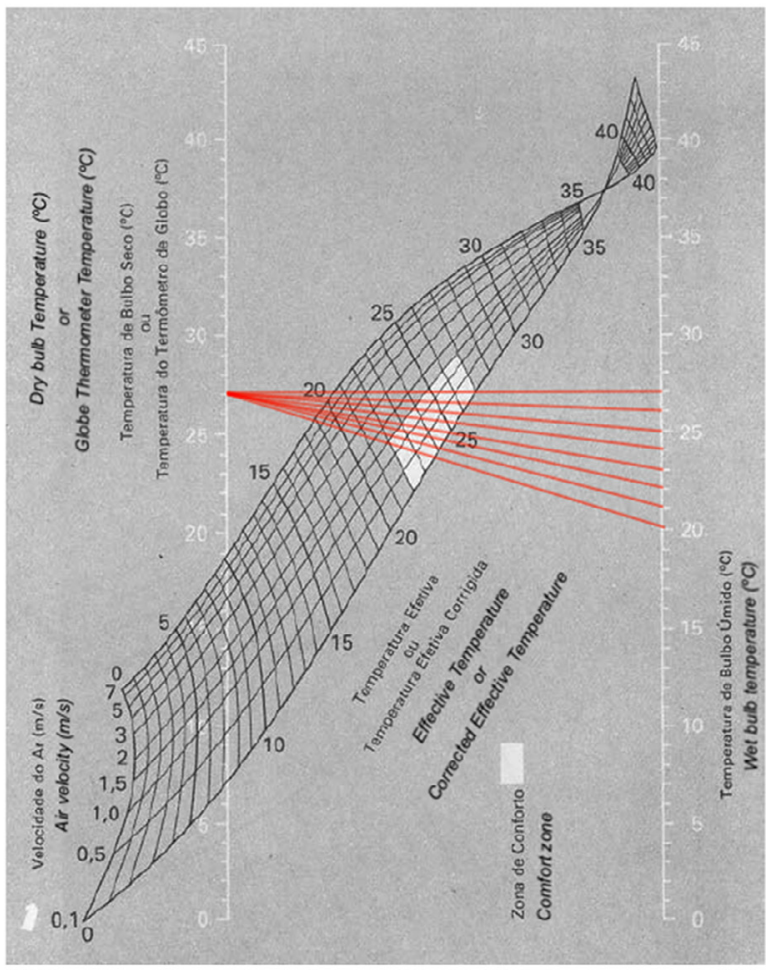

at the Faculty of Agronomic Sciences, FCA, UNESP, Botucatu / SP, Brazil (22 $53^{\prime} 07.9^{\prime \prime}$ S; $\left.48^{\circ} 26^{\prime} 26.1^{\prime \prime} \mathrm{W}\right)$.

\subsection{Weather variables}

The measures required to solve the thermal comfort index were: dry bulb temperature $\left({ }^{\circ} \mathrm{C}\right)$, wet bulb temperature $\left({ }^{\circ} \mathrm{C}\right)$, black globe temperature $\left({ }^{\circ} \mathrm{C}\right)$, dew point temperature $\left({ }^{\circ} \mathrm{C}\right)$, relative humidity $(\%)$ and air velocity $\left(\mathrm{m} \mathrm{s}^{-1}\right)$. The dew point temperature was obtained by Eq. (1) as 
Table 2

Tolerance limits for exposure to heat, in an intermittent work regime with rest periods at the place of service (MINISTÉRIO DO TRABALHO, 2014).

\begin{tabular}{|c|c|c|c|}
\hline $\begin{array}{l}\text { Intermittent work regime with rest at the } \\
\text { workplace (per hour) }\end{array}$ & Light & Moderate & Heavy \\
\hline Continuous work & $\leq 30.0$ & $\leq 26.7$ & $\leq 25.0$ \\
\hline $\begin{array}{l}45 \mathrm{~min} \text { of work } \\
15 \mathrm{~min} \text { of rest }\end{array}$ & $30.1-30.5$ & $26.8-28.0$ & $25.1-25.9$ \\
\hline $\begin{array}{l}30 \text { min of work } \\
30 \text { min of rest }\end{array}$ & $30.7-31.4$ & $28.1-29.4$ & $26.0-27.9$ \\
\hline $\begin{array}{l}15 \text { min of work } \\
45 \text { min of rest }\end{array}$ & $31.5-32.2$ & $29.5-31.1$ & $28.0-30.0$ \\
\hline $\begin{array}{l}\text { Work is not allowed without the adoption of } \\
\text { adequate control measures }\end{array}$ & $>32.2$ & $>31.1$ & $>30.0$ \\
\hline
\end{tabular}

a function of $T_{a}$ and $R H$ (Lawrence, 2005; Alduchov and Eskridge, 1996).

$D_{p}=\frac{B_{1} \times\left[\ln \left(\frac{R H}{100}\right)+\frac{A_{1} \times T_{a}}{B_{1}+T_{a}}\right]}{A_{1}-\ln \left(\frac{R H}{100}\right)-\frac{A_{1} \times T_{a}}{B_{1}+T_{a}}}$

where $D_{p}$ is the dew point temperature $\left({ }^{\circ} \mathrm{C}\right), R H$ is the relative humidity (\%), $T_{a}$ is the air temperature $\left({ }^{\circ} \mathrm{C}\right), A_{1}=17.625$ and $B_{1}=243.04$.

\subsection{Thermal comfort indexes for animals}

Seven parameters of thermal comfort evaluation were implemented for animals from five equations, three for birds, two for cattle and two for pigs. The Temperature and Humidity Index (THI) was used as a way of evaluating the thermal comfort inside the facilities for broilers, cattle and swine, by means of different equations. In Eqs. (2)-(6) are presented the THI calculations for broilers (Eq. (2) (Buffington et al., 1983), dairy cows and cattle (Eq. (3)) (Vitali et al., 2009) and pigs (Eq. (4)) (Roller and Goldmn, 1969; Feher et al., 1983; Gates et al., 1991; Gates et al., 1995).

$T_{\text {birds }}=0.8 \times T_{a}+\frac{\mathrm{RH} \times\left(\mathrm{T}_{a}-14.3\right)}{100}+46.3$

where $T_{a}$ is the air temperature $\left({ }^{\circ} \mathrm{C}\right)$ and $\mathrm{RH}$ the relative humidity (\%).

$\mathrm{THI}_{\text {cattle }}=\left(1.8 \times T_{a}+32\right)-(0.55-0.55 \times R H)\left[\left(1.8 \times T_{a}+32\right)-58\right]$

where $T_{a}$ is the air temperature $\left({ }^{\circ} \mathrm{C}\right)$ and $R H$ the relative humidity in decimal unit.

$T H I_{\text {pigs }}=0.63 \times T_{w b}+1.17 \times T_{d b}+32$

where $T_{w b}$ is the wet bulb temperature $\left({ }^{\circ} \mathrm{C}\right)$ and $T_{d b}$ the dry bulb temperature $\left({ }^{\circ} \mathrm{C}\right)$

The Black Globe-Humidity Index (BGHI), according to Buffington et al. (1981), was used to assess the thermal comfort of birds, dairy cattle and pigs (Eq. (5)).

$B G H I=T_{g}+0.36 \times D_{p}+41.5$

where $T_{g}$ is the black globe temperature $\left({ }^{\circ} \mathrm{C}\right)$ and $D_{p}$ is the dew point temperature $\left({ }^{\circ} \mathrm{C}\right)$.

The Temperature-Humidity-Velocity index (THVI), according to Tao and Xin (2003), was also used for evaluations of thermal comfort of birds (Eq.6).

$T H V I=\left(0.85 \times T_{d b}+0.15 \times T_{w b}\right) \times V^{-0.058}$

where $T_{d b}$ is the dry bulb temperature $\left({ }^{\circ} \mathrm{C}\right), T_{w b}$ is the wet bulb temperature $\left({ }^{\circ} \mathrm{C}\right)$ and $V$ is the air velocity $\left(\mathrm{m} \mathrm{s}^{-1}\right)$.

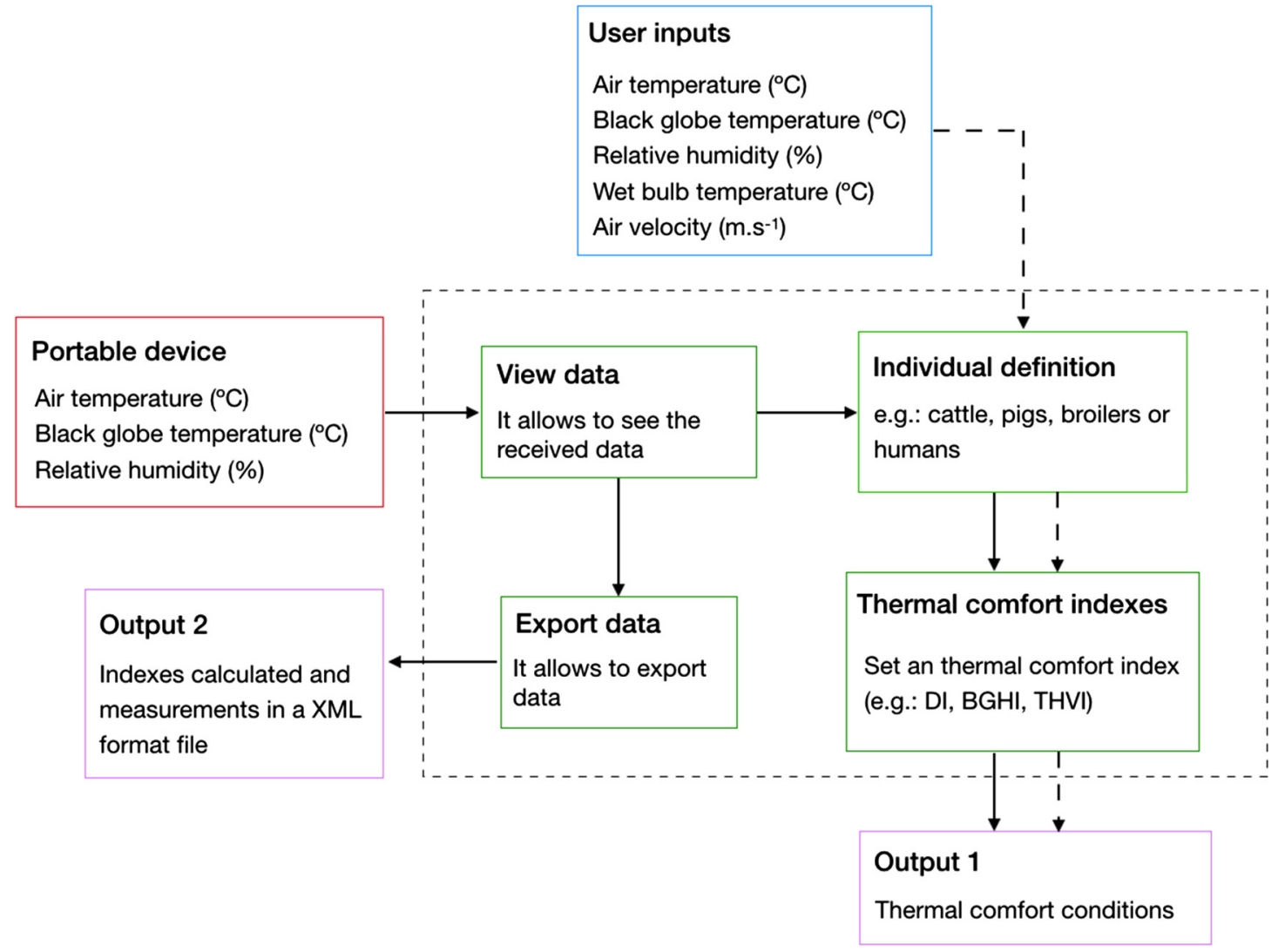

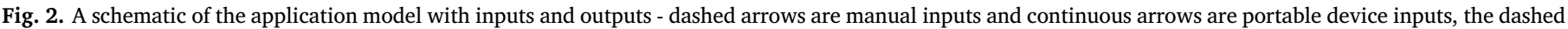
line encompasses the internal components of the application. 
A.

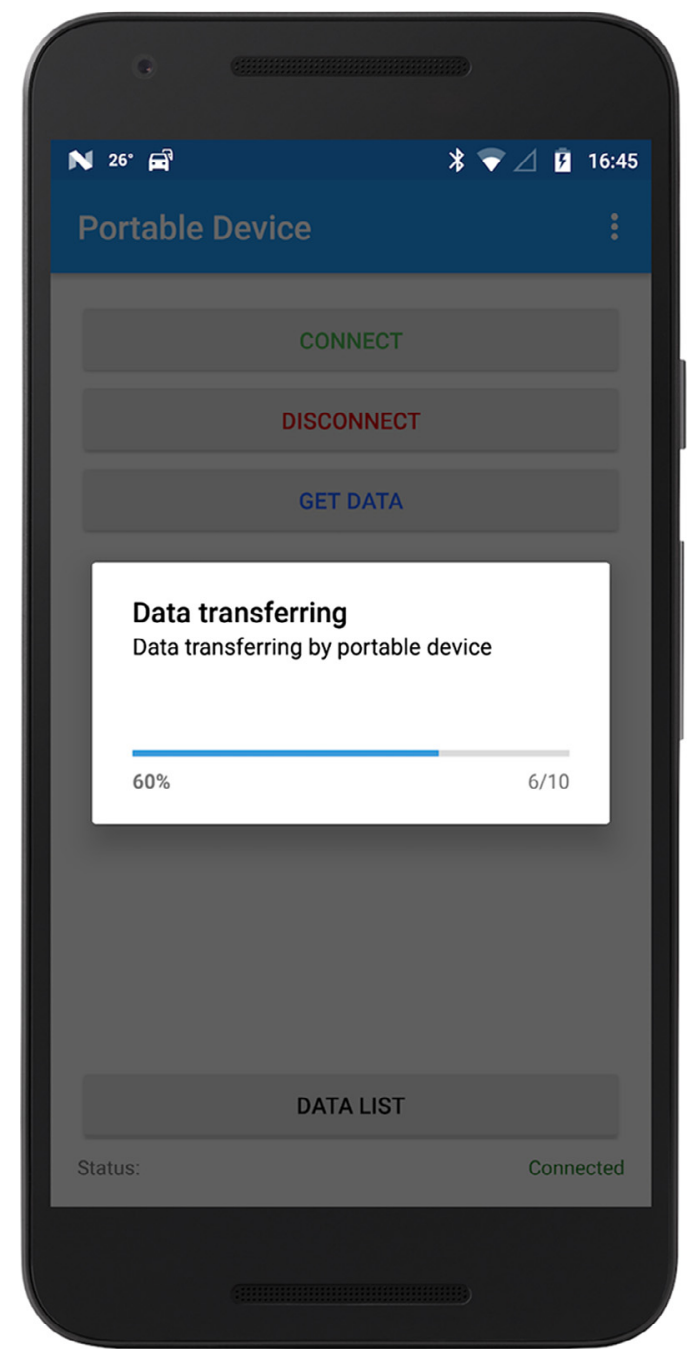

B.

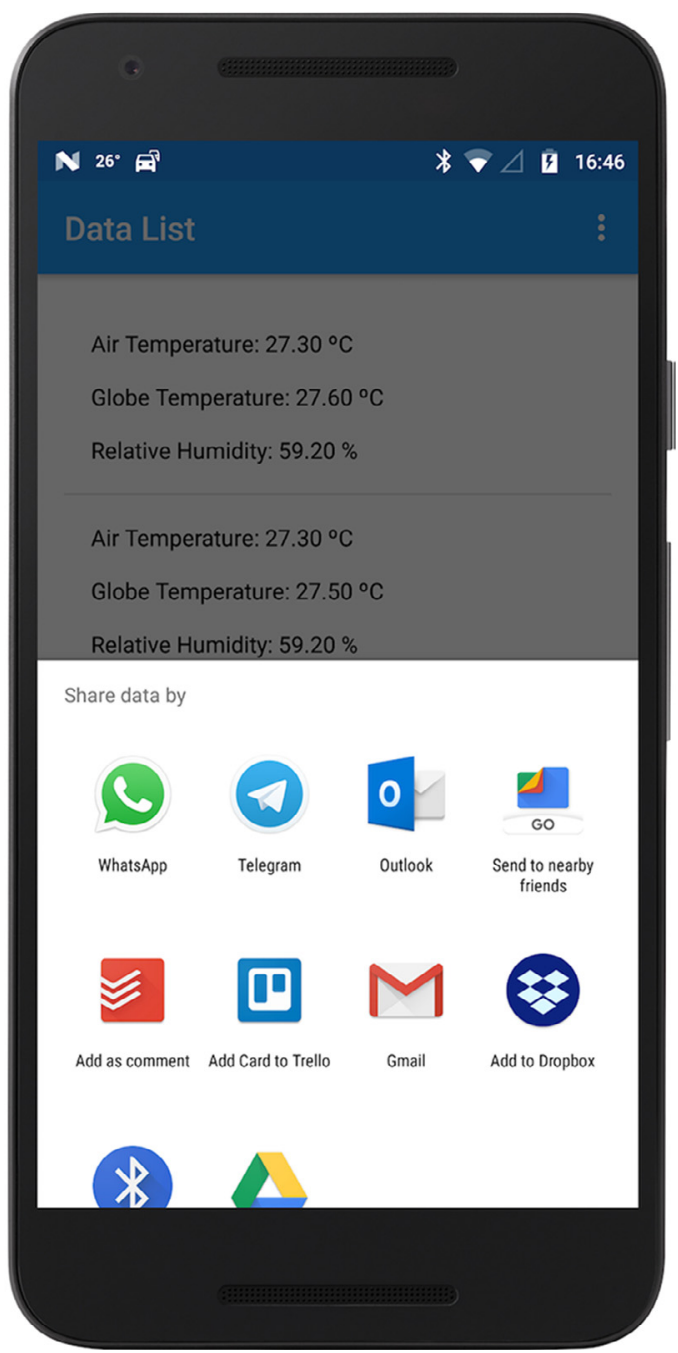

Fig. 3. Screenshots of receiving data via Bluetooth from the portable device (A) and data sharing options with other apps (B).

\subsubsection{Thermal comfort limits}

Table 1 shows the thermal comfort limits according to the BGHI index for broilers (Cândido et al., 2016), cattle (Souza et al., 2004) and pigs (Sampaio et al., 2004; Kiefer et al., 2009) and the THI index for broilers (Silva et al., 2004), cattle (Armstrong, 1994) and pigs (Lima et al., 2007).

\subsection{Thermal comfort indexes for humans}

\subsubsection{Effective temperature index - ETI}

This index was implemented by correlation between dry and wet bulb temperature and air velocity of a nomogram - two-dimensional diagram (Frota and Schiffer, 2006). In Fig. 1(A) the nomogram is shown and in Fig. 1(B) the correlation of the measurements to obtain the effective temperature is applied.

To perform the correlations of the climatological measurements of the nomogram, five matrices of $16 \times 16$ order were created. Each matrix corresponds to an air velocity measurement between 0.0 and $2.0 \mathrm{~m} \mathrm{~s}^{-1}$ (with intervals of $0.5 \mathrm{~m} \mathrm{~s}^{-1}$ ). The columns were defined as the dry bulb temperature measurements, the lines as wet bulb temperature measurements and the intersection between rows and columns as the effective temperature values. The definition of the zones of comfort and discomfort comes from the comparison of the effective temperature value within a limit established between 22 and 27 (blank area of
Fig. 1B). Values less than 22 or more than 27 correspond to the zone of discomfort.

\subsubsection{Globe temperature and humidity index - BGHI}

The BGHI index is calculated by means of two equations (Eqs. (7) and (8)). The values of dry and wet bulb temperature and black globe temperature are used (MINISTÉRIO DO TRABALHO, 2014).

For internal or external environments without solar charge:

$W B G T=0.7 \times T_{w b}+0.3 \times T_{b g}$

where $T_{w b}$ is the wet bulb temperature $\left({ }^{\circ} \mathrm{C}\right)$ and $T_{b g}$ the black globe temperature $\left({ }^{\circ} \mathrm{C}\right)$.

For outdoors with solar charge:

$W B G T=0.7 \times T_{w b}+0.1 \times T_{d b}+0.2 \times T_{b g}$

where $T_{w b}$ is the wet bulb temperature $\left({ }^{\circ} \mathrm{C}\right), T_{b g}$ the black globe temperature $\left({ }^{\circ} \mathrm{C}\right)$ and $T_{d b}$ the dry bulb temperature $\left({ }^{\circ} \mathrm{C}\right)$. Table 2 shows the tolerance limits for heat exposure.

\subsubsection{Discomfort index - DI}

The DI has as input variables temperature and relative humidity of the air, according to Eq. (9) (Thom, 1959).

$D I=0.99 \times T_{a}+0.36 \times T_{d p}+41.5$ 
A.

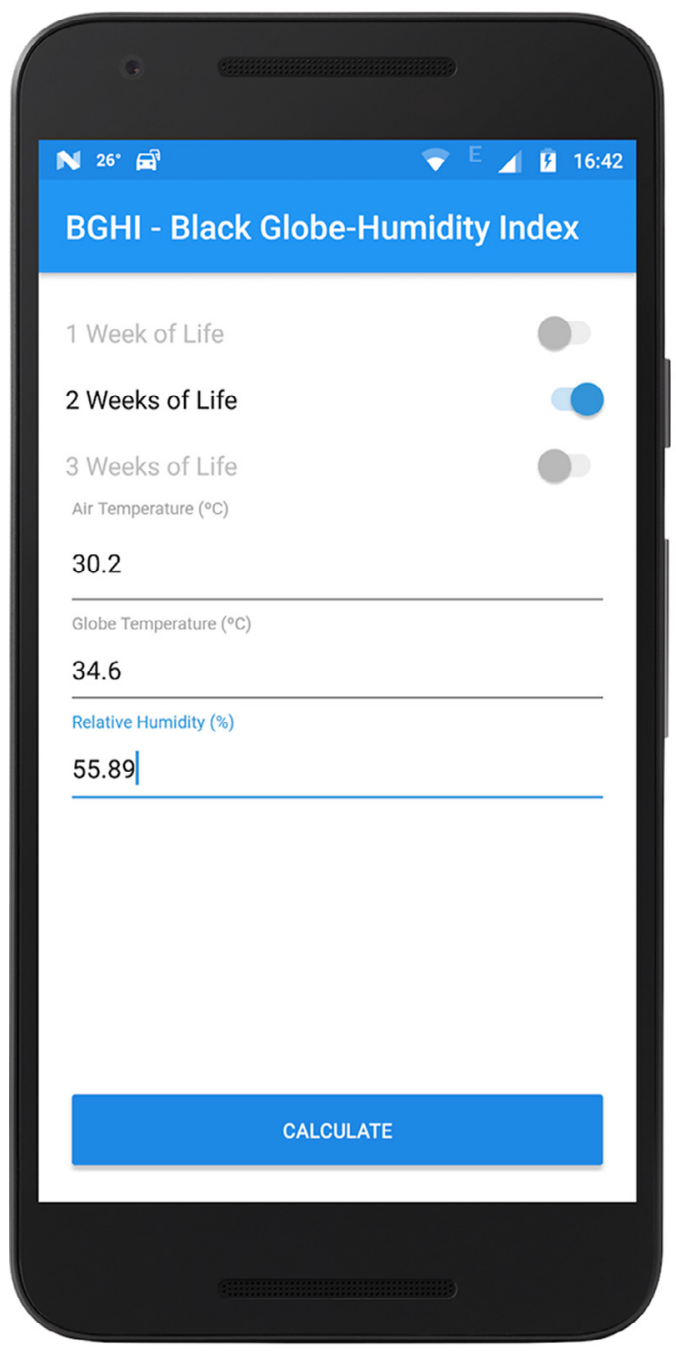

B.

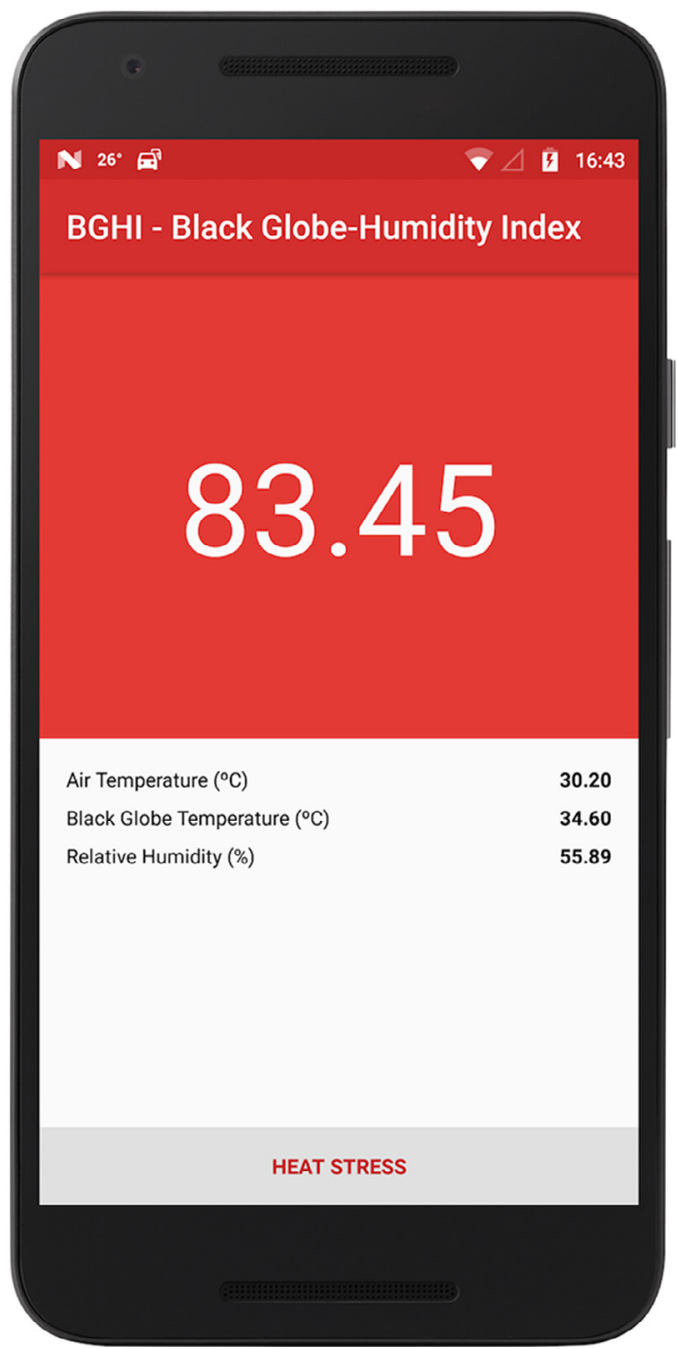

Fig. 4. Screenshots of manual data entry in calculation of the BGHI index for broilers up to two weeks of age (A.) and result of the BGHI index (B.)

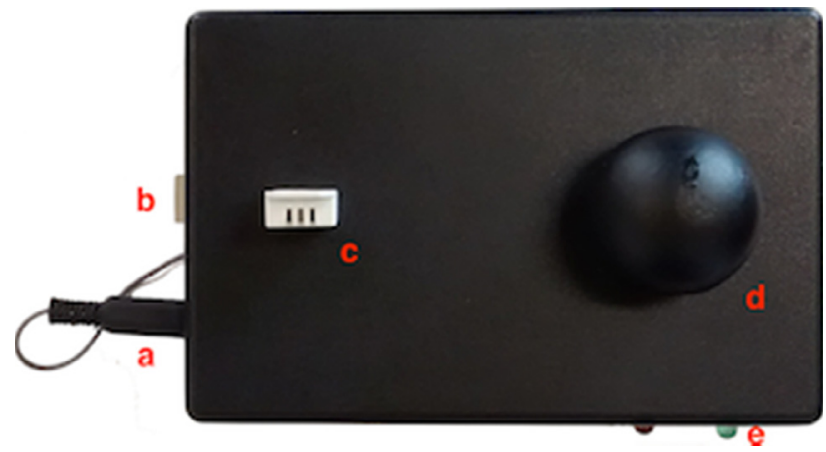

Fig. 5. Top view of portable device: external power supply (a); type B USB input (b); temperature and relative humidity sensor AM2302 (c); black globe thermometer (d); LEDs (e).

where $T_{a}$ is the air temperature $\left({ }^{\circ} \mathrm{C}\right)$ and $T_{d p}$ the dew point temperature $\left({ }^{\circ} \mathrm{C}\right)$.

The thermal comfort limits for the DI are defined as: Comfort for $60 \leq$ DI $<75$, Cold discomfort for $55 \leq$ DI $<60$, Heat discomfort $75 \leq$ DI $<80$, Cold stress for DI $<55$ and Heat stress for DI $>80$ (Ono and Kawamura, 1991).

\subsection{Portable device}

The main component of the portable device, responsible for the processing and transmission of data, was the Arduino Mega $2560 \mathrm{mi}-$ crocontroller (Arduino, 2018), based on the ATmega2560 (Arduino Products, 2018). The Arduino Mega 2560 microcontroller is an open source electronic platform that enables the recording of algorithms using a specific integrated development environment. The Mega 2560 model has 54 digital doors, 16 analog and 256-KB flash memory. As a power source the device operates under DC voltage of $5 \mathrm{~V}$. The AM2302 sensor also known as DHT22 (Aosong, 2015) was used to collect measurements of the temperature, black globe temperature and relative humidity. The sensor is composed of an NTC-type thermistor and a capacitive element for temperature and relative humidity measurements, respectively. It has a resolution of $\pm 0.5^{\circ} \mathrm{C}$ (maximum of \pm $1.0^{\circ} \mathrm{C}$ ) for air temperature measurements, with an operating scale between $-40^{\circ} \mathrm{C}$ and $80^{\circ} \mathrm{C}$. For the measurements of relative humidity its resolution is of $\pm 2-5 \%$, with scale of operation of $0-100 \%$. It has a transmission signal range via Pin 2 (SDA) up to $20 \mathrm{~m}$ (operating conditions DC voltage of 3.3-5.5 V). The BC 417 HC-05 module was used to transmit data via Bluetooth technology. This component operates in slave transmission mode, only capable of receiving connections (or pairings) from other devices. The data transmission range of the Bluetooth module BC $417 \mathrm{HC}-05$ is up to $10 \mathrm{~m}$. As a power source, the 


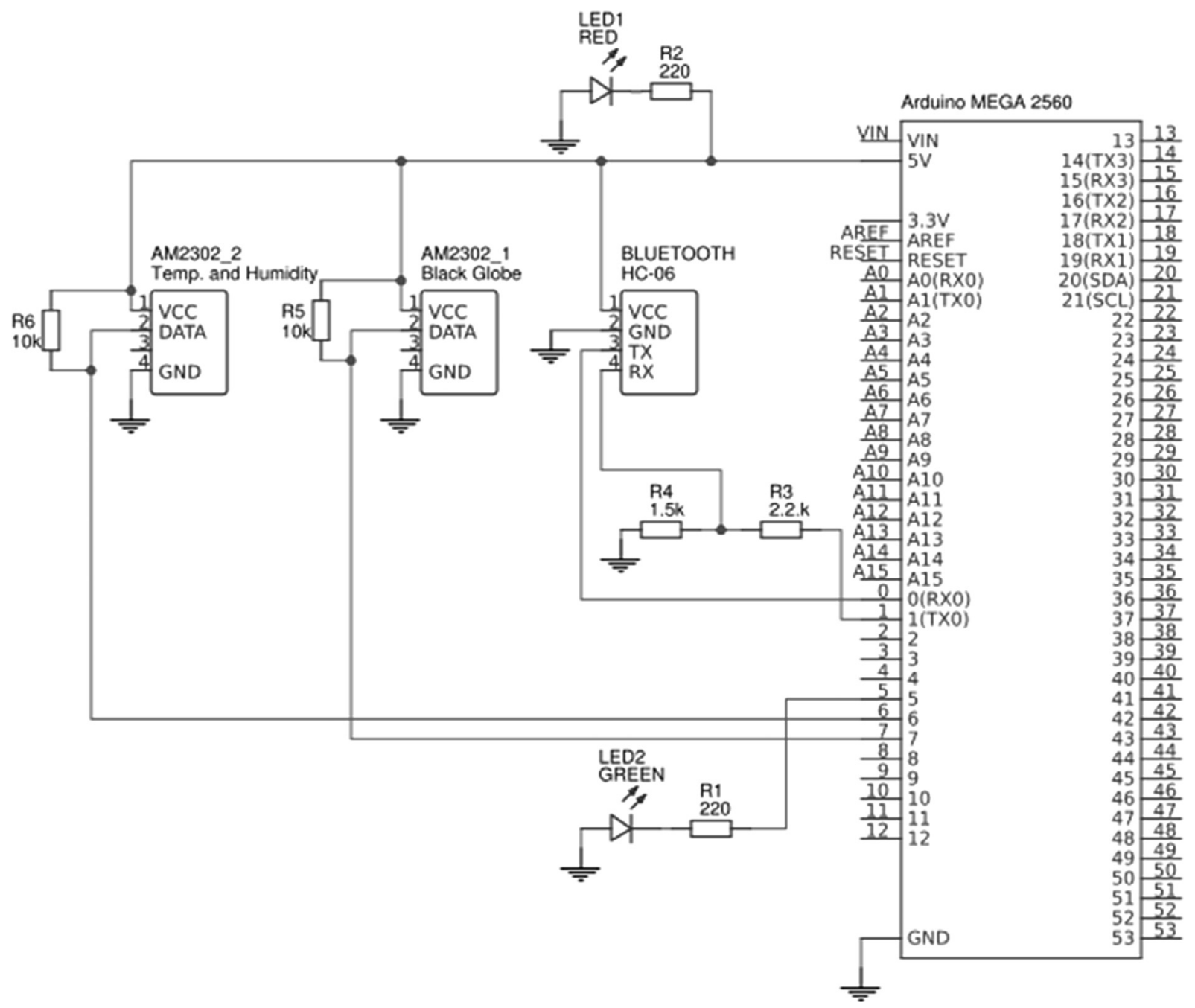

Fig. 6. Schematic diagram of the electronic circuit - portable device.
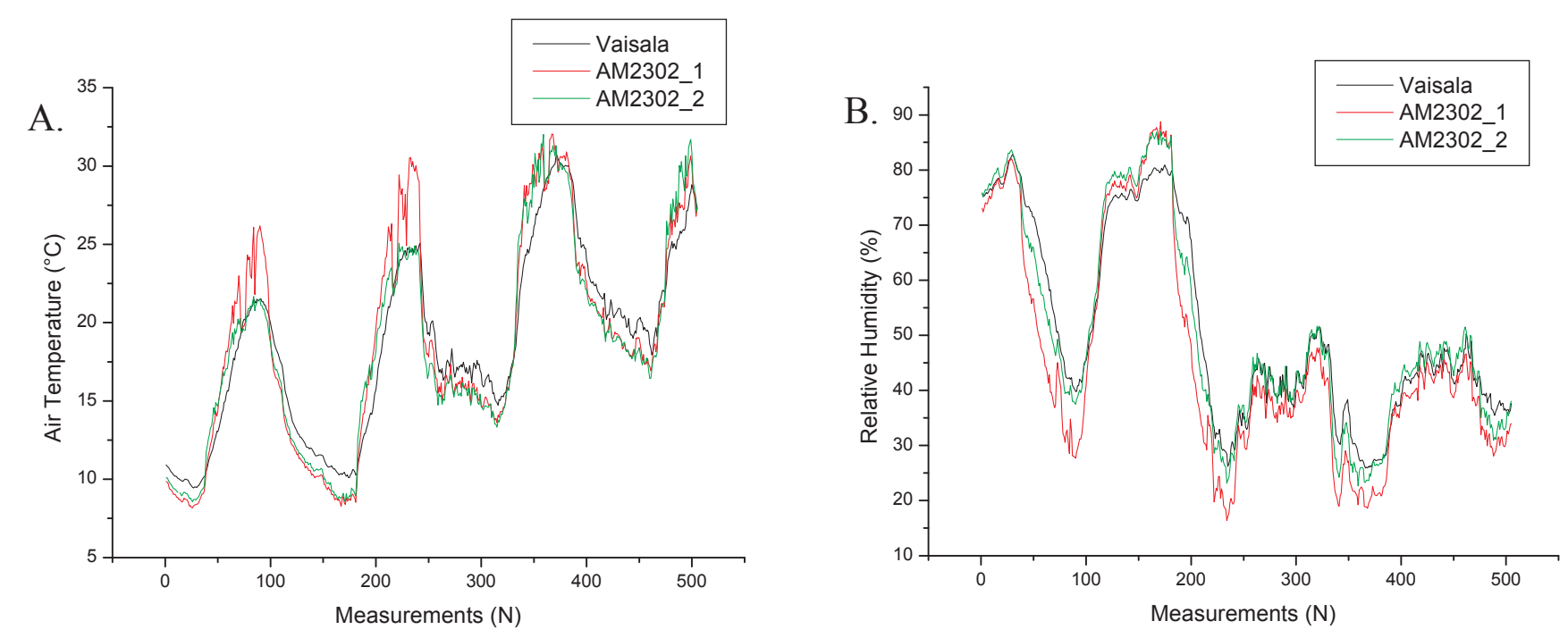

Fig. 7. Measurements of air temperature (A) and relative humidity (B) of Vaisala HMP45C and AM2302 sensors.

device operates under DC voltage of $3.3 \mathrm{~V}$. The data measured by the AM2302 sensor is sent by the BC 417 HC-05 module via the serial communication standard for RX / TX ports.

\subsubsection{Black globe thermometer}

For the development of the black globe thermometer, a hollow plastic sphere of the polyvinyl chloride type (PVC) was used, $36 \mathrm{~mm}$ diameter and $0.5 \mathrm{~mm}$ thick, as recommended by Souza et al. (2002). 
Table 3

Mean and standard deviations of temperature and relative humidity of air between Vaisala HMP45C and AM2302_1.

\begin{tabular}{lllllll}
\hline \multirow{2}{*}{ Day } & Sensor & $\mathrm{N}$ & $\mathrm{T}\left({ }^{\circ} \mathrm{C}\right)$ & \multicolumn{3}{c}{$\mathrm{RH}(\%)$} \\
\cline { 3 - 7 } & & & Mean & St Dev & Mean & St Dev \\
\hline \multirow{2}{*}{$08 / 13$} & Vaisala HMP45C & 139 & 14.71 & 4.16 & 64.9 & 13.8 \\
& AM2302 - 1 & 139 & 14.91 & 5.66 & 59.1 & 18.1 \\
& AM2302 -2 & 139 & 14.48 & 4.43 & 64.2 & 15.4 \\
$08 / 14$ & Vaisala HMP45C & 144 & 16.62 & 5.03 & 55.1 & 19.7 \\
& AM2302 - 1 & 144 & 17.11 & 6.83 & 50.1 & 23.8 \\
& AM2302 - 2 & 144 & 16.24 & 5.38 & 54.7 & 21.4 \\
$08 / 15$ & Vaisala HMP45C & 144 & 22.38 & 5.20 & 38.14 & 7.59 \\
& AM2302 - 1 & 144 & 22.26 & 6.17 & 33.28 & 9.21 \\
& AM2302 - 2 & 144 & 22.00 & 6.09 & 37.68 & 8.83 \\
$08 / 16$ & Vaisala HMP45C & 78 & 22.36 & 3.23 & 41.90 & 4.00 \\
& AM2302 -1 & 78 & 22.07 & 4.49 & 37.91 & 5.84 \\
& AM2302 - 2 & 78 & 22.35 & 5.14 & 41.78 & 6.31 \\
\hline
\end{tabular}

Inside the sphere, the AM2302 air temperature and relative humidity sensor was inserted to perform black globe temperature measurements.

\subsection{Application development}

The entire development of the application was carried out in the software Android Studio AI-141.1989493, through the Java object oriented programming language. Fig. 2 shown a schematic of the application model with inputs and outputs.

\subsection{Data acquisition and validation}

The portable device was inserted in two environments, an office (I) and a swine facility (II), both located in the Fazenda Lageado of the Faculty of Agronomic Sciences, Botucatu (Brazil). It is necessary to specify the time of acquisition of the data in the application, an average value of the measurements made in the period by the portable device was used to calculate the indexes of thermal comfort. The temperature and relative humidity sensor AM2302 was subjected to a previous calibration using the Vaisala HMP45C sensor (Campbell Scientific, 2018). As a form of validation of the portable device the data obtained in the field were compared with those obtained by НОВO U12-012 (Onset, 2018).

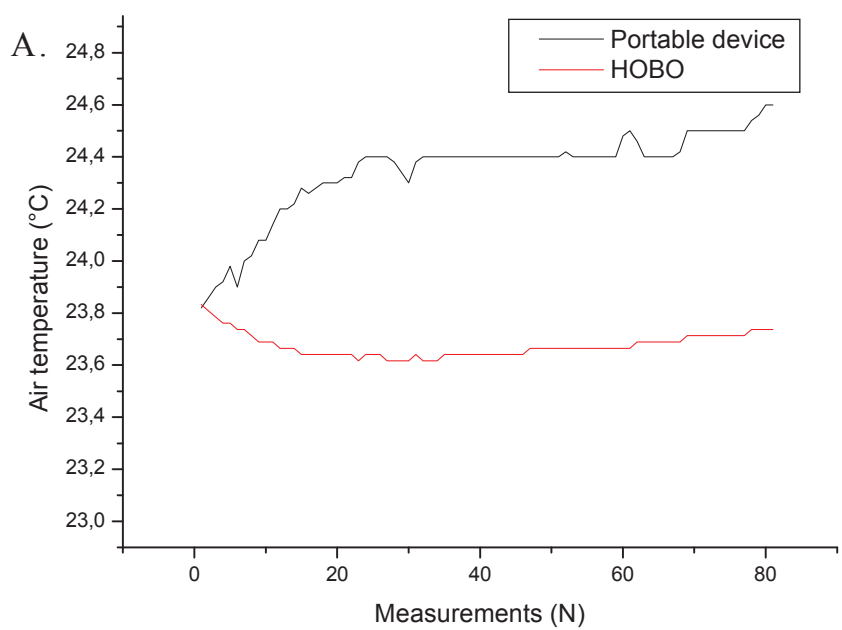

\section{Results and discussion}

\subsection{Android app}

The Android smartphone and tablet app has been developed and published on the Google Play platform and is available in both English and Portuguese versions. For download just access the link https://play. google.com/store/apps/details?id = com.orvalho.

\subsection{Data entry via portable device}

For data entry through the portable device the user must position the device within a radius of approximately $10 \mathrm{~m}$ in relation to the smartphone or tablet, which is the limit distance used for the correct operation of the data transmission via Bluetooth. After the connection between the app and the portable device, it is necessary to set the measurement time - displayed in minutes in a range of 1 to $60(1,2,5$, $10,15,20,30,40,50$ and 60 ). This configuration is required for the data acquisition process to start (Fig. 3A). After completing the data transmission, three options are presented to the user: I. Define individual: it displays the screen of the individuals' list (1. Humans, 2. Broilers, 3. Cattle and 4. Pigs), through the measurements obtained, a certain thermal comfort index is calculated; II. View data: it allows to see the received data; III: Export data: the indexes are calculated, and together with the measurements are exported in a XML format file. After export the user can share the data received by the portable device (Fig. 3B).

\subsection{Manual data entry}

Manual data entry allows to insert data collected by other measuring devices. In this case, the user can evaluate thermal comfort conditions from the mean values of measurement, or maximum and minimum values collected in the environment (Fig. 4).

\subsection{Portable device}

The portable device is an instrument developed to send climatological measurements of air temperature, black globe temperature and relative humidity via Bluetooth connection for Android smartphones and tablets. The device can be powered by a USB port (type B) or by an external $9 \mathrm{~V}$ input. Its electronics components were arranged in a plastic box (cabinet injected under high injection pressure), $36 \times 97 \times 147 \mathrm{~mm}$. Figs. 5 and 6 shows the device and its components in top view and the schematic diagram of the electronic circuit,

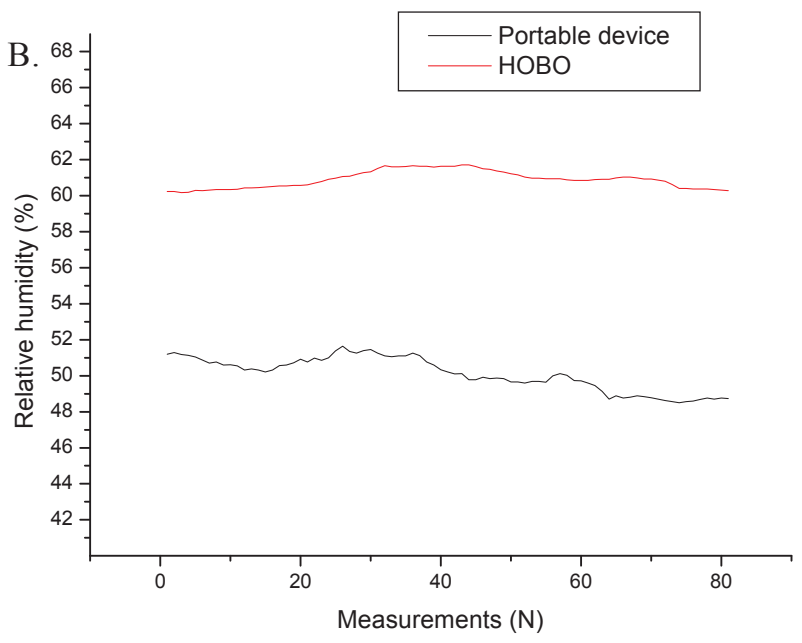

Fig. 8. Measurements of air temperature (A) and relative humidity (B) collected by portable device and HOBO data logger in an office. 

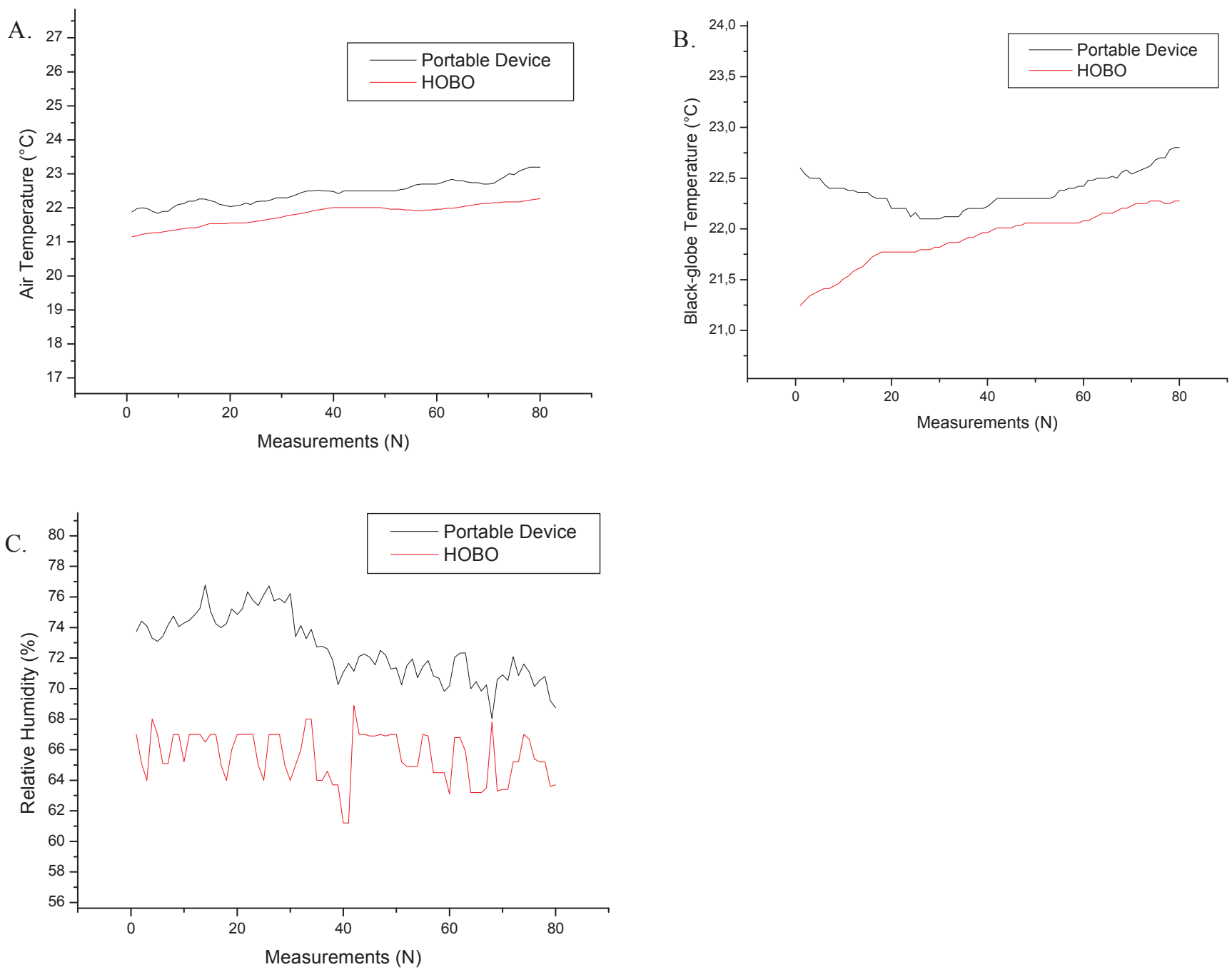

Fig. 9. Measurements of air temperature (A), black globe temperature (B) and relative humidity (C) collected by portable device and HOBO data logger at a swine facility.

respectively.

\subsection{AM2302 sensor calibration}

The temperature and relative humidity sensor AM2302 was calibrated with the Vaisala HMP45C sensor at a meteorological station of the Faculty of Agronomic Sciences, Botucatu (Brazil). Data were collected between August 13 and 16, 2016, at 10 min intervals, totaling 505 data. The measurements of both sensors are shown in Fig. 7.

Table 3 present the mean values and standard deviations of the measurements of the Vaisala HMP45C and AM2302 sensors.

\subsection{Comparative analysis of measurements}

In order to evaluate the correlation between the measurements performed by the portable device and the commercial data logger НОВО U12-012, the devices performed a 40 min collection with reading intervals every $30 \mathrm{~s}$ in an office (Fig. 8).

In this environment an average air temperature of $24.36^{\circ} \mathrm{C}$ (portable device) and $23.67^{\circ} \mathrm{C}$ (data logger HOBO) was obtained. The average measurements of relative humidity were $50.07 \%$ (portable device) and $60.90 \%$ (HOBO data logger). For the Discomfort Index (DI), applying the mean values obtained by the portable device and the HOBO data logger, the values of 70.39 and 70.58 were respectively obtained. In this environment on the basis of the Discomfort Index (DI) both devices led to a thermal comfort condition. The second environment used to compare the measurements of the devices was a swine installation, with the same collection period and reading intervals (Fig. 9).

It was observed a mean air temperature of $22.46^{\circ} \mathrm{C}$ (portable device) and $21.81{ }^{\circ} \mathrm{C}$ (HOBO data logger), a mean black globe temperature of $22.37{ }^{\circ} \mathrm{C}$ (portable device) and $21.91{ }^{\circ} \mathrm{C}$ (HOBO data logger), and a mean relative humidity of $72.67 \%$ (portable device) and $65.83 \%$ (HOBO data logger). For the Globe and Humidity Temperature Index (BGHI), applying the mean values obtained by the portable device and the HOBO data logger, the values of 70.10 and 68.86 were respectively obtained. Both devices led to a thermal comfort condition, according to the BGHI index.

The cost for the creation of the portable device was approximately US $\$ 33.00$, considering only the electronic components, being: a microcontroller Arduino Mega 2560 (US \$ 10.00), two DHT22 air temperature and humidity sensors (US \$5.28), a Bluetooth module 417 HC06 (US \$ 4.60), a black globe - $36 \mathrm{~mm}$ in diameter (US \$ 0.92), a $9 \mathrm{~V}$ alkaline battery (US $\$ 4.92$ ), a storage structure for electronic components - a case box (US \$ 5.04) and a printed circuit board (US \$ 2.26). In addition to the cost of electronic components, to make the Orvalho app publicly available in the Google Play virtual store, we invested over US $\$ 25.00$. Considering the portable device and the application, there was a total investment of approximately US \$ 58.00. It is noted that current methods of thermal comfort analysis, as for example of Carvalho et al. 
(2014), use electronic sensors for measuring climatic variables and a data storage device - data logger (sensors and data logger can be integrated on the same device). The cost of a 6-inch copper ball Instrutherm ESF-206 (Instrutherm, 2018) is approximately US \$ 135.00 (suggested price in Brazil, being: US\$ $1.00 \cong R \$ 3.43-04 / 13 / 2018$ ). An Extech RHT10 Humidity and Temperature USB Datalogger (Extech, 2018 ) is approximately US $\$ 75.00$, while a Tinytag Plus 2TGP-4500 (Tinytag, 2018) can be up to US $\$ 233.00$. In this case, the cost of performing a thermal conditions analysis by measuring the variables of air temperature, black globe temperature and relative humidity is US \$ 217.00 to US $\$ 375.00$. In this way, the portable device obtained a reduction of $75 \%$ to $90 \%$ of the cost commonly applied in equipment for analysis of thermal comfort. However, it is worth mentioning that the cost of manufacturing (labor) was disregarded in the creation of the portable device.

The Orvalho application can be used as an alternative for calculating thermal comfort indexes. Users of specific software for thermal comfort analysis of cattle for Windows platform, such as that developed by Mollo Neto and Nääs (2014) and Mollo Neto et al. (2014), can use the application in on-site analysis where it does not have a personal computer. Likewise, calculations of thermal comfort indexes for swine and broilers (THI, BGHI and THVI), which are also currently performed in software for the Windows operating system, as presented by Angelo et al. (2014), can be done on smartphones and tablets using the Orvalho application. Computer programs developed for PC architectures are efficient when there is the possibility of transport and use of a personal computer in the place where the analysis of the thermal conditions must be performed. Often, obtaining an on-site diagnosis makes it possible to understand whether there is a need for a more detailed analysis of the thermal conditions of that location. The Orvalho application and the portable device can serve as a thermal comfort pre-analysis tool in sheds and animal production facilities. Its use may help in the application of other methodologies and technologies of animal welfare analysis, such as those developed by Sousa et al. (2016), Pereira et al. (2013), Gilkeson et al. (2016) and Li et al. (2017).

When comparing the investment applied to the construction of the portable device, its mobility and the technology used in the present equipment and methods of analysis of thermal comfort of animals and people, a significant gain can be observed with respect to the total cost of the equipment and the form of on-site evaluation granted by the portable device and the app for Android mobile devices. The portability and the easiness of performing calculations of thermal comfort indexes by the application, taking into account the increasing use of smartphones and tablets in the most diverse areas, is also a relevant feature in evaluations and monitoring of thermal comfort realized by small products, researchers and industry.

\section{Conclusion}

An app called Orvalho was developed for Android smartphones and tablets to calculate the thermal comfort indexes of animals and people by manually inserting climatological data or by obtaining data from a portable device via Bluetooth communication. Together with the Android app a low cost portable device was created using an Arduino microcontroller and sensors for air temperature, black globe temperature and relative humidity. The results demonstrated that the Android application and the portable device are functional technologies for thermal comfort assessments in animal and human work environments. By means of on-site measurements it is possible to verify the correct operation of the Orvalho app for the calculation of DI indexes in an office and BGHI in swine facilities.

The Android app allows to obtain a diagnosis of thermal comfort based on the THI, BGHI, THVI, ETI, WBGT and DI indexes. The portable device can be a low cost alternative for measurements of climatological variables in order to evaluate the thermal comfort of environments. In addition, the use of the device along with the app offers several advantages, such as the storage of data on the smartphone or tablet, option to share measurements and thermal comfort indexes through other apps, average data collected in a time interval pre-defined in the study site and easy usability.

\section{References}

Alduchov, O.A., Eskridge, R.E., 1996. Improved Magnus form approximation of saturation vapor pressure. J. Appl. Meteor. 35, 601-609.

Alves, S.P., Silva, I.J.O., Piedade, S.M.S., 2007. Laying hens welfare evaluation: effects of rearing system and bioclimatic environment on performance and egg quality. Braz. J. Anim. Sci. 36 (5), 1388-1394.

Angelo, M.S.P., Nääs, I.A., Vendrametto, O., 2014. Software for estimating thermal comfort in the intensive production of pigs and broilers. Engenharia na Agric. 22 (6), $535-542$.

Aosong, 2015. AM2302. Available on line at: < http://aosong.com/en/aboutus/index. asp $>$.

Arduino, 2018. About. Available on line at: < https://www.arduino.cc/en/Guide/ Introduction $>$.

Armstrong, D.V., 1994. Heat stress interaction with shade and cooling. J. Dairy Sci. 77, 2044-2050.

ASHRAE Standard 55 P, 2010. Thermal Environmental Conditions for Human Occupancy. Third Public Review. American Society of Heating. Refrigerating and AirConditioning Engineers, Inc., Tullie Circle NE, Atlanta, Georgia.

Buffington, D.E., Collazo-Arocho, A., Canton, G.H., Pitt, D., Thatcher, W.W., Collier, R.J., 1981. Black globe-humidity index (BGHI) as a comfort Eq. for dairy cows. Trans. ASAE 24, 711-714.

Buffington, D.E., Collier, R.J., Canton, G.H., 1983. Shade management systems to reduce heat stress for dairy cows in hot, humid climates. Trans. ASAE 26, 1798-1802.

Cândido, M.G.L., Tinôco, I.F.F., Pinto, F.A.C., Santos, N.T., Roberti, R.P., 2016. Determination of thermal comfort zone for early-stage broilers. Agric. Eng. 36 (5), 760-767.

Carvalho, C.C.S., Santos, T.C., Silva, G.C., Santos, L.V., Moreira, S.J.M., Botelho, L.F.R., 2014. Animal and human thermal comfort in poultry houses in Brazilian semiarid. Braz. J. Agric. Environ. Eng. 18 (7), 769-773.

Din, M.F.M., Lee, Y.Y., Ponraj, M., Ossen, D.R., Iwao, K., Chelliapan, S., 2014. Thermal comfort of various building layouts with a proposed discomfort index range for tropical climate. J. Therm. Biol. 41, 6-15.

Extech, 2018. Extech RHT10: Humidity and Temperature USB Datalogger. Available on line at: < http://www.extech.com/display/?id =14707 >

Feher, R.L., Priddy, K.T., Mcneil, S.G., Overhults, D.G., 1983. Limiting swine stress with evaporative cooling in the soulth-east. Trans. ASAE 26 (2), 542-545.

Fernandes, H.C., Moreira, R.F., Longui, F.C., Rinaldi, P.C., Siqueira, W.C., 2011. Effect of heating and cooling of floors in the performance of lactating mothers and piglets. Revista Ceres 58 (6), 701-706.

Fiorelli, J., Fonseca, R., Morceli, J.A.B., Dias, A.A., 2010. Influência de diferentes materiais de cobertura no conforto térmico de instalações para frangos de corte no oeste paulista. Engenharia Agrícola 30 (5), 986-992.

Frota, A.B., Schiffer, S.R., 2006. Manual of thermal comfort: architecture and urbanism, 7. ed. Studio Nobel, São Paulo.

Gates, R.S., Usry, J.L., Nienaber, L.A., Tuner, L.W., Bridges, T.C., 1991. An optimal misting method for cooling housing. Trans. ASAE 34 (5), 2199-2206.

Gates, R.S., Zhang, H., Colliver, D.G., Overhults, D.G., 1995. Regional variation in temperature humidity index for poultry housing. Trans. ASAE 38 (1), 197-205.

Gilkeson, C.A., Thompson, H.M., Wilson, M.C.T., Gaskell, P.H., 2016. Quantifying passive ventilation within small livestock trailers using Computational Fluid Dynamics. Comput. Electr. Agric. 124, 84-99.

Gomes, R.C.C., Yanagi Junior, T., Lima, R.R., Yanagi, S.N.M., Carvalho, V.F., Damasceno, F.A., 2011. Prediction of black globe humidity index and of the impact of climate changes on acclimatized broiler houses. Rural Sci. 41 (9), 1645-1651.

Instrutherm, 2018. ESFERA MOD ESF-206. Available on line at: < https://www. instrutherm.net.br/esfera-mod-esf-206-usada-no-mod-tgd-200-de-cobre-cpm-6 polegadas-de-diametro.html $>$.

Jácome, I.M.T.D., Furtado, D.A., Leal, A.F., Silva, J.H.V., Moura, J.F.P., 2007. Evaluation of thermal comfort indexes for laying-hen houses in the northeast of Brazil. Braz. J. Agric. Environ. Eng. 11 (5), 527-531.

Kiefer, C., Meignen, B.C.G., Sanches, J.F., Carrijo, A.S., 2009. Response of growing swine maintained in different thermal environments. Anim. Arch. 51 (221), 55-64.

Lawrence, M.G., 2005. The relationship between relative humidity and the dewpoint temperature in moist air. Am. Meteorol. Soc. 225-233.

Li, H., Rong, L., Zong, C., Zhang, G., 2017. Assessing response surface methodology for modelling air distribution in an experimental pig room to improve air inlet design based on computational fluid dynamics. Comput. Electr. Agric. 141, 292-301.

Lima, K.A.O., Moura, D.J., Nääs, I.A., Perissinotto, M., 2007. Heat waves influence on milk yield in São Paulo state. Braz. J. Biosyst. Eng. 1, 70-81.

MINISTÉRIO DO TRABALHO 82 P, 2014. NR 15 - Atividades e operações insalubres, Brasília.

Mollo Neto, M., Nääs, I.A., Carvalho, V.C., Conceição, A.H.Q., 2014. Preventive diagnosis of dairy cow lameness. Eng. Agríc. 34 (3), 577-589.

Mollo Neto, M., Nääs, I.A., 2014. Precision farming software to monitor environmental thermal comfort parameters in dairy cattle. Braz. J. Biosyst. Eng. 8 (2), 112-117.

Nematchoua, M.K., Tchinda, R., Orosa, J.A., 2013. Thermal comfort and energy consumption in modern versus traditional buildings in Cameroon: A questionnaire-based statistical study. Appl. Energy 114, 687-699. 
Oliveira Júnior, A.J., Souza, S.R.L., Barros, Z.X., Sartori, M.M.P., Franco, L.V., 2015. Índice de desconforto e índice de temperatura efetiva: uma implementação para smartphones e tablets. Revista Energia na Agric. 30 (2), 155-163.

Ono, H.S.P., Kawamura, T., 1991. Sensible climates in monsoon Asia. International Journal of Biometeorology 35, 39-47.

Onset, 2018. Hobo U12-012. Available on line at: < http://www.onsetcomp.com/ products $>$.

Pereira, D.F., Miyamoto, B.C.B., Maia, G.D.N., Sales, G.T., Magalhães, M.M., Gates, R.S., 2013. Machine vision to identify broiler breeder behavior. Comput. Electr. Agric. 99, 194-199.

Arduino Products, 2018. Arduino Mega 2560. Available on line at: $<$ https://store arduino.cc/usa/arduino-mega-2560-rev3 >

Roller, W.L., Goldmn, R.F., 1969. Response of swine to acute heat exposure. Trans. ASAE 12 (2), 164-169.

Sampaio, C.A.P., Cristani, J., Dubiela, J.A., Boff, C.E., Oliveira, M.A., 2004. Evaluation of the thermal environment in growing and finishing swine housing using thermal comfort indexes under tropical conditions. Rural Sci. 34 (3), 785-790.

Sarubbi, J., Rossi, L.A., Moura, D.J., Oliveira, R.A., Maia, A.P.A., 2012. Nocturnal thermal comfort in facilities for growing swines. Agric. Eng. 32 (6), 1034-1040.

Campbell Scientific, 2018. HMP45C-L Temperature and Relative Humidity Probe. Available on line at: < https://www.campbellsci.com/hmp45c-l > .

Silva, E.T., Leite, D.G., Yuri, F.M., Nery, F.S.G., Rego, J.C.C., Zanatta, R.A., Santos, S.A.,
Moura, V.V., 2004. Determination of the Temperature and Humidity Index (ITU) for the Birds Production in Metropolitan Mesoregion of Curitiba - PR. Revista Acadêmica: ciências agrárias e ambientais 2 (3), 47-60.

Sousa, R.V., Canata, T.F., Leme, P.R., Martello, L.S., 2016. Development and evaluation of a fuzzy logic classifier for assessing beef cattle thermal stress using weather and physiological variables. Comput. Electr. Agric. 127, 176-183.

Souza, S.R.L., Nääs, I.A., Marcheto, F.G., Salgado, D.D., 2004. Analysis of the ambient conditions in systems of freestall lodging for dairy cows. Braz. J. Agric. Environ. Eng. $8(2 / 3), 299-303$.

Souza, F.T., Tinôco, I.F.F., Baêta, F.C., Ferreira, W.P.M., Silva, R.S., 2002. Evaluation of the alternative materials to make a globe thermometer. Ciênc. Agrotec. 26 (1), $157-164$.

Tao, T., Xin, H., 2003. Acute synergistic effects of air temperature, humidity, and velocity on homeostasis of market-size broilers. Trans. ASAE 46 (2), 491-497.

Thom, E.C., 1959. The discomfort index. Weatherwise 12, 57-59.

Tinytag, 2018. Rugged, waterproof temperature and relative humidity logger with builtin sensors. Available on line at: < https://www.geminidataloggers.com/dataloggers/tinytag-plus-2/tgp-4500 > .

Vitali, A., Segnalini, M., Bertocchi, L., Bernabucci, U., Nardone, A., Lacetera, N., 2009. Seasonal pattern of mortality and relationships between mortality and temperaturehumidity index in dairy cows. J. Dairy Sci. 92 (8), 3781-3790. 